Cinémas

Revue d'études cinématographiques

Journal of Film Studies

\title{
Audio-visual Mediation : Reconfiguring the Discursive Problematic of Cinema and History
}

\section{Tollof Nelson}

Volume 11, numéro 1, automne 2000

Écritures dans les cinémas d'Afrique noire

URI : https://id.erudit.org/iderudit/024839ar

DOI : https://doi.org/10.7202/024839ar

Aller au sommaire du numéro

Éditeur(s)

Cinémas

ISSN

1181-6945 (imprimé)

1705-6500 (numérique)

Découvrir la revue

Citer cet article

Nelson, T. (2000). Audio-visual Mediation : Reconfiguring the Discursive Problematic of Cinema and History. Cinémas, 11(1), 153-168.

https://doi.org/10.7202/024839ar
Résumé de l'article

Cet article se veut une esquisse des questions soulevées dans leurs textes par des intellectuels, des théoriciens et des historiens dans deux anthologies récentes. Tout en renouvelant la problématique de la représentation de l'histoire dans l'optique de la médiation audio-visuelle, les deux anthologies véhiculent un "débat " implicite qui traverse et qui divise les intérêts de l'investigation académique en Amérique du Nord et en Europe. Ce qui semble être une préoccupation commune, le poids de l'histoire dans le cinéma, n'est que la marque d'une division nette, emblématique des valeurs et des orientations institutionnelles divergentes. 


\section{Audio-visual Mediation: Reconfiguring the Discursive Problematic of Cinema and History}

\section{Tollof Nelson}

\section{RÉSUMÉ}

Cet article se veut une esquisse des questions soulevées dans leurs textes par des intellectuels, des théoriciens et des histcriens dans deux anthologies récentes. Tout en renouvelant la problématique de la représentation de l'histoire dans l'optique de la médiation audio-visuelle, les deux anthologies véhiculent un "débat" implicite qui traverse et qui divise les intérêts de l'investigation académique en Amérique du Nord et en Europe. Ce qui semble être une préoccupation commune, le poids de l'histoire dans le cinéma, n'est que la marque d'une division nette, emblématique des valeurs et des orientations institutionnelles divergentes.

\section{ABSTRACT}

This brief article maps out some of the central concerns and questions raised in two relatively recent anthologies of essays by major intellectuals, film scholars and historians. In addition to problematizing the representation of history and audio-visual media, these two anthologies examplify the circulation of ideas, the bridges as well as the divisions between the interests of academic inquiry in North America and Europe. What seems to be a common preoccupation, the weight of history in cinema, is only the marker of a clear line of division which is emblematic of divergent values and institutional orientations. 
All of the essays in this volume deal with transformations in the sense and representation of history which emerged at the beginning of the twentieth century, correlative with the birth of cinema, modernity, and "modernism" [...] with the ways in which film and television respond to, interrogate, and create contemporary history [...]. (Sobchack, 1996, p. 7)

En animant ce séminaire, notre souhait était de réfléchir à la manière dont le cinéma contribue à la vitalité et la diversité des réflexions actuelles sur l'écriture et le statut de vérité de l'histoire... (de Baecque and Delage, 1998, p. 13)

Juxtaposing these opening editorial remarks, both of which address in their own way the problematic of cinema and the persistence of history, one is immediately tempted to begin an archaeological dig into the discursive settings that divide academic inquiry in North America and Europe. Historically, neither anthology addresses the other '; yet each has a way of reverberating, echoing, and disturbing the voices of the other significantly. While both editors envision wide-ranging themes, neither shares the initial premises of the other; whereas Antoine de Baecque and Christian Delage objectify the contributions of cinema conservatively as a vitalizing and diversifying force in the domain of a philosophical discourse of history already honorably established, Vivian Sobchack underscores how the advent of modernist cinema and other forms of audio-visual technique have upset this very discursive framework, ushering in a period of radical transformation about the representation, interrogation and production of history.

Without reducing the richness of the diverse articles included in these anthologies, it might be helpful to paraphrase the opening articles of each volume as they best stake out the debate and to highlight the keywords, conceptual notions, and discourses that animate this debate. The main purpose of such a double reading is to produce a field of tensions that reveal how a series of fundamental problems in the critique of historiography have been reformulated, reassessed, and reconfigured by cinema and 
television studies in terms of audio-visual mediation. The following subject headings provide an indication of the recurring problems and issues that mark this discursive change.

\title{
Nuancing the truth of fiction and history: the contract of the modernist event
}

It becomes extremely interesting to compare the anthologies by discussing the essays of Roger Chartier ("La vérité entre fiction et histoire") and Hayden White ("The Modernist Event"). If the critique of historiography seems to have become a sophisticated and complex debate of problems of rhetoric and theories of narration, one may do well to consult Chartier's essay for some clarification regarding the historical development (from Hegel to Michel de Certeau) of the fundamental question of the "truth of the narrative of history." Both Chartier and White agree that the question of truth cannot be reduced to being an inquiry into the conditions of formal narrativity, of merely locating narrative poetics within the traditional typologies of rhetorical figures. Instead, the question of truth, explored in the problematic conflation of fiction and historical knowledge, must be discussed in terms of the mediating relationship to reality or "contract" established historically between texts and readers or between screens and spectators. In Chartier's opening words,

\begin{abstract}
[...] "le statut de vérité du récit d'histoire" concerne, elle, le contrat passé entre l'écriture de l'histoire et le lecteur de l'histoire quant à l'accréditation du récit comme vrai, ce qui renvoie aux parentés et aux différences existant entre toutes les formes de l'écriture narrative, qu'elle soit d'histoire ou de fiction [...] cette problématique est proche de celle qui vous est familière et qui s'interroge sur le statut de la vérité dans le contrat passé entre le spectateur et le film et sur les effets de réalité produits par les différentes techniques de la reproduction des images. (p. 29)
\end{abstract}

It is clear from this statement, and from the absence in this essay of any other rernarks made in reference to the reproduction of images, that Chartier considers film as a case of the problem of fiction. Yet one may ask, can the insights generated by the 
critique of historiography, and enumerated throughout Chartier's essay, be grafted so easily onto the problem of the audio-visual mediation of events throughout the twentieth century? This question may be brought into focus by considering what Hayden White has called the transformation, between the nineteenth and twentieth centuries, of the "historical event," discussed again in terms of transformation of the mediating relationship or contract:

The relationship between the historical novel and its projected readership was mediated by a distinctive contract: its intended effects depended upon the presumed capacity of the reader to distinguish between real and imaginary events, between "fact" and "fiction," and therefore between "life" and "literature." (p. 18)

While reviewing the universally contested status and interpretation of Oliver Stone's film, JFK (1992), White goes on to contend that the post-modernist docu-drama or the historical metafiction dissolve this "contract," which originally mediated between the nineteenth-century author and reader, not so much by reversing the distinction between the real and the imaginary but by placing these distinctions "in abeyance" (p. 19). A consequence of this dissolution, White argues, is that

[...] the notion of "the historical event" has undergone radical transformation as a result of both the occurrence in our century of events of a scope, scale, and depth unimaginable by earlier historians and the dismantling of the concept of the event as an object of a specifically scientific kind of knowledge. The same is true for the notion of "story;" it has suffered tremendous fraying and an at least potential dissolution as a result of both that revolution in representational practices known as cultural "modernism" and the technologies of representation that made possible by the electronics revolution. (p. 22-23)

Following this argument, White links the problem of the loss of transmittable experience, wisdom, and knowledge (the virtualization of the "storyteller" as discussed by Walter Benjamin), to what Frederick Jameson has described as the "de-realization" 
of the event. White goes on to discuss how this loss was in turn explored as a de-realization by literary and filmic modernism,

\section{[...] by constantly voiding the event of its traditional narrativistic function of indexing the irruption of fate, destiny, grace, fortune, providence, and even "history" itself into a life [...] and give the life thus affected at worst a semblance of pattern and at best an actual, transsocial, and transhistorical significance. (p. 24-25)}

In Hayden White's essay, images of twentieth century catastrophies are discussed, from Chernobyl to the Holocaust, and explosive cases of social interpretation, from the Rodney King video to the explosion of the space shuttle Challenger, in order to qualify the "explosive" and the "unstable, fluid, and phantasmagoric" power of the images of modern media. These images have exerted endless fascination and debate precisely because they are impervious to explication and resistant to narrative representation. The effort to slow the medium down, to bring its images under the control of words available for subjects within the purview of the culture of "literate" television-journalism, was only exacerbated by the repetitive frequency of their transmission, manipulation, and transformation.

It is in this last sense that White nuances the question of truth and the problem of the dissolution of the "contract" alluded to earlier. The modernist images of film, video, and television do not merely constitute a case in the historiography/fiction debate as implied by Chartier, but open up a series of questions about the new conditions for the mediation of the truth of historical events. According to White, these new conditions are intimated by the emergence of techniques of fictional modernism (stylistic innovations are discussed with reference to substantial citations from Jean-Paul Sartre, Virginia Woolf, and Gertrude Stein). For this reason, the "anti-narrative" techniques of these writers (i.e. the existential shard, the vagrant interval, or the fusion of the inside/outside of stories ${ }^{2}$ ) are not raised polemically as a critique of historiography since they explore and open new relations to the temporality of the word and the unveiling of truth. Rather than negate "the burden" of history, these 
modernist techniques hold out another possibility for sealing a "contract" with audio-visual culture: the capacity to negotiate traumatic experience in the presence of the phenomenal explosion of images and to mourn what is unsayable in the scrambled sense of events witnessed in the twentieth century.

\section{Personal and collective memory and mourning: subject positions of the Shoah}

Paul Ricœur's erudite essay "Mémoire et histoire" opens the anthology De l'histoire au cinéma, addressing broad epistemological issues of historical knowledge and cultural memory. Like Chartier's article, it is clear that for Ricour the problems posed by the history of cinema and the powers associated with cinematic history/memory are implicitly situated in the midst of this larger philosophical problematic of the mediation of memory; these problems and powers of cinema invoke and open a discursive site of questioning, unexplored by Ricœur's earlier work, Temps et récit (1983-1985). However, for the editors of the anthology this questioning seems less a discursive concern and more of a thematic strategy since they somewhat reduce Ricœur's remarks in an effort to circumscribe all the essays within this predicament:

Loin de constituer un simple catalogue d'informations sur ce qui s'est passé, le cinéma construit avec ses spectateurs une relation esthétique et historique... voire même idéologique... nous aidant à mieux comprendre la corrélation entre l'“intériorité de notre mémoire" et le "processus de notre socialisation" (Paul Ricœur), entre une représentation du monde (le cinéma) et la manière dont les hommes vivent dans ce monde (l'histoire). (p. 15)

Ricœur, while never specifically mentioning the place of cinema among these issues or any particular films, does foreground his epistemological inquiry by mentioning the gaps and the excesses of the memory of WWII, the danger of such widely available "corrective" collective memory and the possibilities of transforming it. This underscores a concern with the way historical knowledge is contested, rewritten, and therapeutically confronted with the processes of and pathologies of personal and collec- 
tive memory. The central question becomes, in Ricœur's words, "comment la connaissance historique s'articule-t-elle sur le travail de souvenir et le travail de deuil?” (p. 23)

In order to prepare the ground for this question, Ricœur discusses the difficulty of establishing anything more than an analogical "correlation" between the ontological concept of "interior memory" (St. Augustine/Hegel/Locke) and the merely operative, sociological concept of "collective memory" (Halbwachs). The dilemma is posed in the following terms: "Quand on parle de mémoire collective, faut-il alors supposer l'existence d'une mémoire collective? Halbwachs n'hésitait pas à le faire; mais alors qui est le sujet qui se souvient? Peut-on parler d'un sujet collectif?" (p. 19) Dissatisfied with Husserl's solution, by which we may speak of intersubjectivity, or the transposition of the subject onto the collective categories of identity and consciousness, Ricœur decides to break with the philosophical tradition which forbids thinking beyond the singular/collective analogy: he proposes the hypothesis of a direct correlation between two subjectivities, individual and collective, that mutually constitute one another (p. 20). Ricour justifies this hypothesis on the basis of the most common phenomenological experience of mediation and memory:

Pour se souvenir, même de façon solitaire et privée, il faut recourir à un médium langagier: le souvenir est un discours que l'on se tient à soi-même. Platon définissait déjà la dianoia, la pensée, comme un dialogue que l'âme se tient à elle-même. Il n'y a pas de mémoire sans langage. Or, la médiation du langage est d'emblée de rang social. [...] Cette convergence de faits - médiation langagière, médiation narrative de la mémoire la plus privée - conduit à se demander si l'intériorité présumée de la mémoire n'est pas corrélative du processus de socialisation. Ce serait dire qu'intériorité et socialité se constituent simultanément et mutuellement. Au fond, avant l'échange langagier, l'échange narratif, il n'y a que la dispersion d'une vie, qui ne trouve sa connexité, sa cohésion, que dans la connexion narrative qui est publique. (p. 20) 
This insight, regarding the correlation of the individual subject to a collective subject through the mediation of language, is corroborated and expanded by a discussion of the work of two key thinkers on the subject of history and memory: the application of Reinhart Koselleck's "Augustinian" notion of historical consciousness as a sense of orientation in time structured on a personal and collective level; and the possibility of applying Freud's pathological categories of individual memory to collective memory. This allows him to discuss the problematic mediation of traumatic memory, situated as it is in the wounds and scars of the collective and individual memory of events. Finally, historical consciousness, grief and melancholy are related to Ricœur's preoccupation with the "subject" of narrative and time; since literary narrative is a homeostatic model of historical narrative, featuring the prototypical tropes, configurations, and resources for the emplotment of history and of persona, its potential for generating other positions paves a way by which an individual or collective subject might negotiate the experience of traumatic events:

\begin{abstract}
Raconter autrement, mais aussi être raconté par d'autres. Or, dans une histoire racontée autrement, les événements ne sont plus les mêmes, dès lors que leur place dans l'histoire est changée. Ces variations narratives ont une fonction critique remarquable au regard des formes les plus figées par la répétition, les plus ritualisées par la commémoration. On voit là à l'œuvre le travail du souvenir mais aussi celui du deuil. Raconter autrement et être raconté par les autres, c'est déjà se mettre sur le chemin de la réconciliation avec les objets perdus d'amour et de haine. (p. 23)
\end{abstract}

Like Hayden White in his essay previously discussed, Ricœur sees the possibility in literary fiction of assuming the burden of history and mediating the traumatic memory of modern events; whereas White emphasizes the renewed contract made possible through the techniques of fictional modernism, Ricœur insists on the reconciling work of repetition and commemoration inherent in collective and singular acts of narrativity. While both White and Ricœur problematize the connection between 
the medium of language and narrative mediation, only White goes on to discuss their relationship to the techniques of audiovisual mediation. Nevertheless, Ricœur does leave room for speculation by redefining a theory of the subject in the context of collective and singular memory in a setting itself organized by the larger problem of mediation.

The possibilities and the limits of this theory might be tested were we to discuss the memory of the subject in the historical and cross-cultural context of the cinematic representation of the Holocaust. We may refer to Thomas Elsaesser's important article in the Sobchack anthology, "Subject Positions and Speaking Positions from Holocaust, Our Hitler, and Heimat, to Shoah and Schindler's List." At the more historical level of popular cinema, and especially in the representation of the history of Fascism and Nazism by Hollywood post-war cinema and Neo-Realism, Elsaesser somewhat follows the path pointed to by Ricœur's central question. He emphasizes how several generations of contemporary directors in cinema and television have offered perspectives on the way in which historical knowledge is articulated alongside the work of memory and the work of grief and mourning.

According to Elsaesser, with the advent of audio-visual media (in which the divide between memory and History is being crossed and recrossed in either direction, and where the past is "digitally remastered"), History has entered a conceptual twilight zone, lost its hold on public interest, and has become the very "signifier of the inauthentic:"

No longer is storytelling the culture's meaning-making response, but something closer to therapeutic practice has taken over, with acts of re-telling, remembering, and repeating all pointing in the direction of obsession, fantasy, and trauma. If civil wars, communal strife, and tribal violence suggest a compulsion to repeat at the level of action-because buried memories, rekindled by fresh hatred and local grievance, seek to redress wrongs suffered centuries ago-what obscure urge is soothed by the compulsion to repeat so typical of television? (p. 146)

Audio-visual Mediation: Reconfiguring the Discursive Problematic of Cinema and History 161 
Elsaesser expands on these remarks by insisting that cinema, as the American "public art," has allowed the history of the Vietnam War to go beyond the "history books," for instance. By association, such a statement challenges what Ricœur's text defines as the work of reconciliation inherent in the repeated storytelling of historical memory:

\begin{abstract}
C'est en s'initiant à la confrontation entre écritures historiques rivales que les mémoires malades s'exercent non seulement à raconter autrement, mais à structurer différemment la compréhension qu'elles prennent d'elles-mêmes au niveau des causes et des raisons. À cet égard, je voudrais souligner l'importance du phénomène de réécriture. (p. 26)
\end{abstract}

Elsaesser might reply: what about the confrontation between films exploiting the ills of an endlessly rewritten and war-torn memory? Films such as those representing the Vietnam War (The Deer Hunter, Cimino, 1978; Apocalypse Now, Coppola, 1979; Full Metal Jacket, Kubrick, 1987; Platoon, Stone, 1986; Dear America -Letters from Home, Couturie, 1987), do not bear witness to one history or even to plural histories but have produced "history" by doing the "mourning work" of a nation, for a nation with a burdened conscience.

Without directly critiquing Ricœur's ideas, we may try to test their scope, their pertinence, and their limits in the historical context of cinema, by deliberately setting them against some of the poignant remarks and questions Elsaesser poses throughout his essay. These questions themselves are organized by the problem of audio-visual mediation, for Elsaesser explores and evokes them in the context of what he calls "the subject positions and speaking positions" of individual and collective memory, particularly the historical memory repeatedly transformed and contested in several generations of cinema and television. Such a "confrontation" will in turn allow us to expose what is at stake in political terms by asking the following series of pointed questions, which emerge from a critical engagement with Elsaesser's text:

Can the "obscure urge" of television and cinema exorcise buried memories, "soothed by the compulsion 
to repear." itself qualified as a "conciliatory" act of retelling? (p. 146)

What would such a reconciliation mean when it continuously produces "a secularized and debased response" in a "melodramatic interpretation" of historical events of the "incomprehensible" magnitude of the Holocaust? (p. 148)

In the context of the postmodern debate on the historical representation of Auschwitz, and in the effort to safeguard the memory of such terror-beyond an "epistemologically compromised form of realism" or the "silent despair before the incomprehensible" - what would it mean for cinema to preserve the sense of Jean-François Lyotard's imperative of "the sublation, or the double negation: the effort to preserve the fact that the unrepresentable exists?" (p. 148)

Do such films need to be "ruled by an aesthetics of detachment and distarice" in a modernist hermeneutic of pathos and irony to be worth their intellectual salt, or is there a healthy purpose at work in the popular, spectacular culture of obsessive memory, in the highly charged emotions and affective responses produced by these films and television series-even when they elicit the "excessive, perverse, and compulsive" affects of violence, "melodrama, sentimentality and prurience?" (p. 150)

To what extent can we lend credence to either critical impulse, whether it be "ironically detached" or "emotionally excessive" when both are grounded, to some extent, in cinema's "postmodern hubris," namely the implicit "theodicy" or claim "[...] to redeem the past, rescue the real, and even rescue that which was never real?" (p. 166)

Is the idea of "mourning work" in cinema or television seriously worthy of defense as an essential form of historical knowledge in the twentieth century, or is it merely a hollow pretext to valorize films that stop short of self-pity and sentimentality "[...] acknowledging compassion only at the price of playing victims off each other in the vain hope of squaring accounts?" In other words, is the idea of a "reconciling confrontation" between individual and collective memory in the public sphere of film a pretentious "over-evaluation of the political impor- 
tance of the aesthetics of moral rectitude," according to which "the experience of one's own loss may serve as a prelude to acknowledging the loss of others?" (p. 171-172)

These questions and problems are opened up as Elsaesser describes the divided "subject positions" among the directors of the New German Cinema of the 1970's-1980's, including Werner Herzog, Wim Wenders, Hans Jürgen Syberberg, Alexander Kluge, Helma Sanders-Brahms, Volker Schlöndorff, Edgar Reitz, Rainer Werner Fassbinder, and Marcel Ophüls. Explaining how these directors assumed paradoxical "speaking positions" of alienation and representation when responding to the Fascist past, the Federal Republic and the possibility of German unification, Elsaesser evokes the problems of identification, identity politics, and the price of empathy. His remarks come to a head in words that are explicitly central to Ricœur's own enterprise:

But if "mourning work" cannot open up that space of otherness, what can? What kinds of affect might possibly "unlock" numbness, apathy, indifference, and reconcile memory and hope, commemoration and forgetting, or mediate between pity, sentiment, and shame? [...] In the face of narcissistic forms of identification in conventional narrative and fictional dramatization, such an "affect of concern" is meant to break through any coherent and thus comforting subject position and shock spectators into recognition. Yet such strategies of shock, increasingly used to convey the suffering caused by human or natural disasters, also imply the deeply ambiguous modes of address typical of news broadcasts and current affairs programs: soliciting (emotional) response, while disempowering (civic, political) action. (p. 172)

Such dilemmas help to refocus the generic divide between documentary and fiction film according to the "ambiguous or extreme subject positions they are able to sustain" rather than according to the traditional distinctions of "what they show or do not show," whether "one is more or less authentic than the other" (p. 173). Particular attention is given throughout the essay to the spectrum of differences between two notoriously 
opposed films, Shoah (Claude Lanzmann, 1985) and Schindler's List (Steven Spielberg, 1993), contrasted in the following terms:

Two kinds of eschatology, then, seem to confront each other: the tragic vision of life of the European Jew Lanzmann, and the life-affirming vision of the American Jew Spielberg. [...] By affirming that whoever saves one life, saves mankind, Spielberg accepts the principle that the one can represent the many, that the part can stand for the whole. Shoah is based, explicitly and emphatically, on the exactly opposite premise: that no one can stand in for anyone else. After six hours of testimony in Shoah-a testimony that, in different ways, records only absence, one is left with the overwhelming thought that no history can contain, let alone signify or represent, the palpable reality of so many individual, physical deaths. (p. 178)

Yet the problems of "representation" underscored by the confrontation between these films as they negotiate two contrary forms of personal/collective memory also serve to highlight the problems of the subject/speaking positions that films project and sustain.

The collision between the two films implies, aesthetic, moral, as well as religious differences, but it also includes the most constitutive division in film history between Hollywood and Europe, itself a scene where the same drama seems destined to play itself out over and over again. I want to take this case, and look once more at the relationship between historical events and their representations, but also at what it means to bear witness--especially when public history has inevitably superseded personal memory - and to speak for someone, or find oneself spoken by someone, in the medium of cinema. (p. 147)

Yet what does it mean for a subject to speak in the context of a hypermediated world, when speaking is no longer grounded in the mere exchange of language for a subject who "stands by" his word with other subjects, as Ricœur might have it; when speaking-even political speech-is always already an act of ventriloquism "voiced-over" into microphones, speakers, and screens of 
audio-visual media, an act of "throwing one's voice" or finding oneself "thrown" in the new cultural sphere of public history and memory? As Elsaesser argues, even a "historical unconsciousness," itself part of "representing history," may be made to speak in the subject positions framed by a film's mode of address. What happens to the subject of speech in this "postmodern condition of contemporary cinema," when even "the text no longer speaks for the author?" (p. 175)

No modernist defense like "exile, silence, and cunning"
can protect the filmmaker as author, but the public
arena of magazine and television interviews, published
diaries and essays, the promotional machinery that
makes the director "speak." These speaking positions, I
think, need not refer to biographical individuals, nor
even to "auteurs," but are instances of historical and
personal accountability. It is in this context that one
can view the one-sided exchange between Lanzmann
and Spielberg. (p. 175)

Elsaesser goes on to describe how the subject positions of both films, determined by their respective genres when touching upon an identity politics of historical and religious values that neither can transcend, both work "[...] on the borders of the unified and the shattered self." (p. 177) According to Elsaesser, Lanzmann, while attempting to evoke a documentary history for which there is neither redemption nor exorcism, suspending all preconceived and unifying narratives and explanations, still very carefully created a "persona" for himself, a kind of phantasmic and "Dantesque" super-ego of the voices heard and unheard, of the faces seen and unseen, of the memories coaxed or left undisturbed.

Lanzmann works with each individual memory as a unique "archaeological" site, requiring different tools and different techniques. Whether he flattened someone's complacency or patiently stalks someone else's elusiveness, whether he takes the man who shaved the women at Treblinka back to his barber shop or listens to the prisoner from Chelmo tell how his singing voice saved his life, Lanzmann creates a multitude of speaking positions by separating them as 
sharply from each other as possible, while embedding them in sympathy, even when they must have appalled him or when pity threatened to overwhelm him. (p. 174)

Spielberg, on the other hand, while providing a master-narrative transgressing the taboo of narrative emplotment, strategically shatters viewer identification by projecting melodramatic sentiment in a fictional form bordering on the perverse; yet reappropriates the "fashioned" reality of the history on the movie production sets in the streets of Krakow, in the after-life of the ghetto "scene," which became a famous shot-on-location.

More generally, and more paradoxically, Spielberg, by putting into circulation a discourse which suggests that this was a "personal" film, has given himself the license to do exactly the opposite: namely to speak on behalf of others, to make the step from direct testimony and personal memory, to narrative and history. (p. 179)

These paradoxes show at once how easily and yet how ambiguously Ricœur's ideas of collective and personal memory, as simultaneous and mutually constituting subjects, may be applied to the cultural phenomenon of cinema.

For to the extent that a film creates a public sphere, a space for discourse, confrontation and debate, it is this space that produces the speaking positions which in turn are the external limits of representation. One reason for dwelling on these examples is that they underscore the difficulties, when taking facism as the "limir" case of historical representation, of determining any author's speaking position, yet also assert the necessity of doing so in each case. (p. 179)

It is clear that Elsaesser sees the historical necessity and hope of assuming or inventing an ethics of responsibility to "account" for all of the repeated inversions, reversions, and perversions of subject positions and speaking positions that have obsessively recalled the traumatic events such as the Shoah/Holocaust. In this, there is the expectation and the hope of an ethos committed to understanding how historical knowledge, contested, thera-

Audio-visual Mediation: Reconfiguring the Discursive Problematic of Cinema and History 
peutically confronted, and rewritten in the grief and mourning of memory, has become inevitably and irretrievably the predicament of positioning the subject for speech outside of the mediation of language in the audio-visual techniques of television and cinema.

\section{Université de Montréal}

\section{NOTES}

1. Vivian Sobchack's anthology was edited over several years as a response to a lecture given by meta-historian Hayden White on "The Modernist Event" sponsored by the American Film Institute (1992). De Baecque and Delage's anthology was edited from transcriptions of conferences given in a research seminar entitled, "Histoire, cinéma, répresentations", from 1995-1997 at the Institut d'histoire du temps présent (CNRS).

2. These terms are my own way of paraphrasing Hayden White's descriptions of the very complex modernist poetics of these writers (p. 25-36).

\section{WORKS CITED}

Chartier, Roger. "La vérité entre fiction et histoire," in Antoine de Baecque and Christian Delage (editors), De l'histoire au cinéma. Bruxelles: Éditions Complexe, 1998, p. 29-44.

De Baecque, Antoine and Christian Delage (editors). "Présentation," De l'histoire au cinéma. Bruxelles: Éditions Complexe, 1998, p. 13-15.

Elsaesser, Thomas. "Subject Positions, Speaking Positions from Holocaust, Our Hitler, and Heimat to Shoah and Schindler's List" in Vivian Sobchack (editor), The Persistence of History: Cinema, Television, and the Modern Event. New York: Routledge, 1996, p. 145-183.

Ricoeur, Paul. "Histoire et Mémoire," in Antoine de Baecque and Christian Delage (editors), De l'histoire au cinéma. Bruxelles: Éditions Complexe, 1998, p. 17-28.

Sobchack, Vivian (editor). "Introduction: History Happens," The Persistence of History: Cinema, Television, and the Modern Event. New York: Routledge, 1996, p. 114.

White, Hayden. "The Modernist Event," in Vivian Sobchack (editor), The Persistence of History: Cinema, Television, and the Modern Event. New York: Routledge, 1996, p. 17-38. 